\title{
Objekti ja tegevuse leksikaalne markeeritus eesti õppijakeeles
}

\author{
PILLE ESLON \\ Tallinna Ülikool
}

Ülevaade. Uurimus on osa laiemast projektist, milles võrreldakse õppijakeelt eesti keele fraseoloogilise ainese ja standardkirjakeelega. Artiklis käsitletakse objekti ja tegevust iseloomustavate leksikaalsete markeritega (markeeritud) ning ilma markeriteta ( Ø-markeeritusega) objektifraase ja kirjeldatakse nende kasutuspiiranguid. Objektifraasid on leitud erinevatest keelekasutusvariantidest teksti- ja sõnastikusageduse põhjal: valitud on vaid lauses verbist paremale jäävad objekti sisaldavad kontekstid. Objektifraasid on reastatud verbivormide sageduse alusel, misjärel on välja arvutatud iga tüvemorfeemi osakaal eesti õppijakeeles ja fraseoloogilises aineses. Erinevate valimite põhjal saadud andmete võrdlusest nähtub, et nii sagedaste tuumverbide kui ka harva esinevate täistähenduslike verbide esindumus on samalaadne. Käesoleva uurimuse tarbeks on valitud nelja kõige sagedasema verbi (andma, tegema, võtma ja saama) objektifraasid. Järgnenud kvalitatiivses analüüsis ning tulemuste interpreteerimisel ei tugineta fraasistruktuuri grammatikale ega semantilistele rollidele, vaid objektifraasi markeerituse metamõistele, mille abil on lingvistikas tavaliselt kirjeldatud foneetiliste tunnuste ja morfoloogiliste kategooriate opositsioone. Artiklis on vastandatud leksikaalsete markeritega (markeeritud) ning leksikaalsete markeriteta (Ø-markeeritusega) objektifraasid. Objekti on eesti õppijakeeles määratletud tavaliselt kvaliteedi- ja kvantiteedisõnadega, tegevust adressaadi ning kvantiteedi- ja rõhusõnadega. Uurimus võimaldab vastata küsimusele, miks on objekti ja tegevust leksikaalselt 
markeeritud (määratletud), miks jäetud markeerimata; missugused on objektifraasi markeerituse/markeerimatuse semantilised, leksikaalgrammatilised, morfosüntaktilised ja struktuursed piirangud.

Võtmesõnad: eesti õppijakeel; leksikaalne markeerimine; objektifraas

\section{Sissejuhatus}

Markeerimine ehk määratlemine on metamõiste, mille abil on lingvistikas kirjeldatud keele struktuuri, foneetiliste tunnuste ja morfoloogiliste kategooriate vastandusi (opositsioone), samuti keele asümmeetrilisust, sünkretismi ja neutraliseerumist (reduktsiooni), keeleuniversaale, keeltevahelisi seoseid, lähte- ning sihtkeele häälduse, grammatika ja sõnajärje omandamise raskusastmeid, keeleüksuste markeerituse (määratletuse) seost tekstisageduse, keelekasutuse ökonoomia, optimaalsusega jm (vt Haspelmath 2006). Lisaks on uuritud niisuguseid keelendite markeerituse tunnusjooni nagu morfofonoloogiline ja morfosüntaktiline keerukus, hierarhilisus, regulaarsus, loomulikkus, konkreetsus/abstraktsus, prototüüpsus, ikoonilisus, sünkretism, analoogiapõhisus jm (vt Eckman jt 1986; Eckman 1977, 1991; Croft 1988; LaPolla 1995; Lahiri 2000; Lee 2001; Haspelmath 2008b; Schaden 2008; Jin 2008; Remes 2009; Aalberse, Don 2011). Niisiis on markeerituse abstraktset mõistet olnud erinevates uurimustes ja teoreetilistes üldistustes mugav rakendada (vt ülevaated markeerituse teooria kujunemisest Praha koolkonnast tänaseni Moravcsik, Wirth 1986; Barlow, Ferguson 1988; Battistella 1990; Croft 2003).

Siinses uurimuses on markeerituse mõistet kasutatud nii objektifraasi analüüsi- ja kirjeldamise meetodina kui ka teoreetilise raamistikuna, mille alusel keelekasutust interpreteerida-põhjendada (vt ka Haspelmath 2008a: 42-43; Harbour 2011). Tähelepanu all on objekti ja tegevuse leksikaalne markeerimine ehk määratlemine (nt ei saa head töö, teevad meist laulurahva) või selle puudumine ehk leksikaalselt $\varnothing$-markeeritusega objektifraasid (nt andma abi, tegema eksperimente). 
Joseph H. Greenberg on väitnud, et põhjalik keelekasutuse analüüs peab lisaks kõigele muule sisaldama tekstisageduse analüüsi, sest sel fenomenil on oluline teoreetiline väljund: sagedus võimaldab seletada keeles varjus olevaid nähtusi ja protsesse, püstitada hüpoteese ja ennustada. Greenberg on uurinud vene keele käänete tekstisageduse distributsiooni ja jõudnud järeldusele, et käändekasutus on otseselt seotud noomeni semantikaga ning see pole juhuslik. Sageduse arvessevõtmist on ta pidanud oluliseks ka markeerituse hierarhia esiletoomisel. (Greenberg 1990: 218-220.) Varasemates funktsionaalsetes ning nüüdsetes kasutuspõhistes, konstruktivistlikes ja kognitiivsetes korpuslingvistilistes uurimustes on tekstisagedust vaadeldud korrelatsioonis struktuuri keerukusega. Zipfi seaduse järgi on keeleüksuse lingvistiline keerukus pöördvõrdeline selle sagedusega (mida keerukam, seda harvem esineb ja vastupidi). Seda aksioomi saab seostada keeleüksuste markeerituse ja variatiivsusega (nt Pustet 2009; Yamaguchi 2008).

Kuigi kasutussagedus pole keelestruktuuri asümmeetrilisuse esiletoomisel kõige olulisem, seletab see siiski, et suhteliselt sagedamini kasutatud keelendeid tajub kõneleja tavalise, lihtsa ja seega loomulikuna, suhteliselt vähem sagedasi keelendeid aga suhteliselt keeruka ja vähem loomulikuna, harva esinevaid keelendeid peetakse kas ebaloomulikuks (hälve) või erandlikuks, individuaalseks. Siinses uurimuses käsitletaksegi objekti ja tegevuse leksikaalse markeerituse/markeerimatuse seost esinemissagedusega. Markeerituse ja sageduse mõisteid rakendatakse selleks, et kirjeldada objektifraasi semantilisi, leksikaalgrammatilisi, morfosüntaktilisi ja struktuurseid piiranguid, vastandades üksteisele lihtsad (loomulikud) ning keeruka(ma)d keelestruktuurid.

Varasemas uurimuses on teksti- ja sõnastikusageduse võrdluse põhjal esile toodud objektnoomeni käändevormide kasutusele omane nominatiivi ja partitiivi vastandus, mille markeeritud liikmeks on eesti keeles partitiiv. Morfoloogilise vastanduse markeerimata liikme kasutus on alati diferentseeritum ja esinemissagedus väiksem kui markeerimata liikmel. Emakeelekõneleja tajub loomulikuna partitiivi-genitiivi asendusi nominatiiviga, sama loomulikuks peab ta ka objektikäänete 
varieerumist koos aspektverbidega ning kolme grammatilise käände neutraliseerumist ehk käändeerisuse redutseerumist. Siinkohal näide tavalisest varieerumisest: Kui rahvas saaks valida Ilvese, siis ta valiks Ilvese $\sim$ Kui rahvas saaks valida Ilvest, siis ta valiks Ilvest $\sim$ Kui rahvas saaks valida Ilvest, siis ta valiks Ilvese Kui rahvas saaks valida Ilvese, siis ta valiks Ilvest. (Eslon, Õim 2010: 69, 72, 79-84.) Diakrooniliselt on eesti keeles välja kujunenud ühe- ja kahesilbiliste sõnade vormihomonüümia ehk käändesünkretism, mis on läänemeresoome keeltes üldine ja viitab paradigma loomulikule lihtsustumisele erinevate morfofonoloogiliste ja keelemuutuslike protsesside tulemusena (vt Grünthal 2010: 106 jj). Õppijakeele objektifraasi käändekasutust analüüsides saab markeerituse mõiste abil interpreteerida nii sageli/harva esinevaid kui ka normipäraseid/normivastaseid käändeasendusi - esimesi tajub emakeelekõneleja tavalise ja loomulikuna nagu andis põhjuse $\sim$ põhjust, teisi kas marginaalse või ebaloomulikuna nagu näiteks genitiivi ja partitiivi asendamine nominatiiviga tavapärast markeerimata (S)VO sõnajärge muutmata: ${ }^{\star}$ andis välja kalender, ${ }^{\star}$ loob maailm jt (vt Eslon 2011: 53 jj).

Markeerituse mõistet on mugav rakendada ka keelekasutusele tüüpiliste kontekstide esiletoomiseks, milles esineb piiranguid sõna- ja vormivalikus, nt vene keele imperfektiivse ja perfektiivse aspekti vastandust või aspektiopositsiooni neutraliseerumist diferentseerivad kontekstid (vt Бондарко 1971; Шелякин 1983; Эслон, Пихлак 1993). Analoogselt saab esile tuua ka eesti keele objektifraasid, mis tavapäraselt sisaldavad või ei sisalda objekti ja tegevust referentsiaalselt määratlevaid lekseeme ehk markereid, nt objekti kvalitatiivne konkretiseerimine adjektiivide ja pronoomenite abil: tegime ${ }^{\star}$ naljakas foto, anda täpset ${ }^{*}$ vastest, saa head tööd, võtsid oma esindajad jne. Leksikaalsete markerite kasutamist või kasutamata jätmist käsitletakse siinses uurimuses vastavalt objektifraasi markeerituse ja markeerimatusena ( $\varnothing$-markeeritus). Seejärel püütakse välja selgitada, mille poolest leksikaalselt markeeritud objektifraasid erinevad markeerimata objektifraasidest, mida ning kuidas on markeeritud, missugune on verbivormide ja markerite esindumus jm. Niisiis ei tugineta siinses objektifraasi analüüsis ei fraasistruktuuri grammatikale 
ega semantilistele rollidele, vaid vaadeldakse objekti ja tegevuse leksikaalse määratlemise võimalusi ja selle puudumist kõigis objekti sisaldavates ning lauses verbist paremale poole jäävates kontekstides.

\section{Materjali valik}

Keeleaines on valitud kahest allikast: "Eesti vahekeele korpuse" rohkem kui 500000 sõne suurusest osast (edaspidi EVKK) ja "Eesti fraseologismide elektroonilisest alussõnastikust" (edaspidi FES). Eesmärk oli kontrollida, kas erinevate valimite võrdlemisel tuleb esile eesti keelekasutusele iseloomulik ühisosa, millele saaks muuhulgas tugineda ka objektifraasi korpusanalüüsis. Sel eesmärgil on EVKK-st ja FES-ist välja sorditud kõik objektifraasid ning leitud korduvad ja ainukordsed verbitüved. Seejärel on valimeid võrreldud tüvede esinemissageduse ja tüve osakaalu alusel valimis. Iga konkreetse tüve osakaal on arvutatud valimis esinenud tüvede üldkogumi suhtes. Selle põhjal saab välja tuua keskmiselt sama sageli ja sama harva kasutatud verbid, mille osakaal võrreldavates valimites jääb samasse vahemikku. Teisisõnu: teksti- ja sõnastikusageduse alusel leitud seosed kahe valimi verbikasutuse arvandmete vahel näitavad samalaadsust mõne sageli kasutatud transitiivse tuumverbi ja mõne harva esineva transitiivse täistähendusliku verbi vahel (vt tabel 1, tärniga on esile toodud eesti õppijakeele andmed). Kõige suurem on lahknevus kahe valimi vahel tuumverbiga andma $(0,026643)$ ja kõige väiksem täistähendusliku verbiga jooma (0,000032), ent kõik arvnäitajad andmaverbist kuni jooma-verbini jäävad samasse nullilähedasse vahemikku, mis räägib võrreldavate valimite samalaadsusest (vt tabel 1). ${ }^{1}$

\footnotetext{
1 Aitäh Katre Õimule fraseoloogilise ainese analüüsi ja korduvate verbitüvede võrdluse eest EVKK-s ning FES-is.
} 
TABEL 1. Verbitüvede osakaal EVKK ja FES-i valimites

\begin{tabular}{|c|c|c|c|}
\hline Tüved & Sagedus & Osakaal & Vahe \\
\hline AND & 144 & 0,082711 & \multirow{2}{*}{0,026643} \\
\hline $\mathrm{AND}^{*}$ & 237 & 0,056068 & \\
\hline PIDA & 41 & 0,023550 & \multirow{2}{*}{0,007495} \\
\hline PIDA $^{*}$ & 127 & 0,030045 & \\
\hline TEGE & 210 & 0,120620 & \multirow{2}{*}{0,007064} \\
\hline TEGE $^{*}$ & 480 & 0,113556 & \\
\hline MÄNGI & 82 & 0,019399 & \multirow{2}{*}{0,005039} \\
\hline MÄNGI* & 25 & 0,014360 & \\
\hline VÕT & 164 & 0,038798 & \multirow{2}{*}{0,003761} \\
\hline VÕT $^{*}$ & 61 & 0,035037 & \\
\hline NÄITA & 70 & 0,016560 & \multirow{2}{*}{0,001052} \\
\hline NÄITA* & 27 & 0,015508 & \\
\hline SAA & 136 & 0,078116 & \multirow{2}{*}{0,000993} \\
\hline $\mathrm{SAA}^{*}$ & 326 & 0,077123 & \\
\hline JAGA & 15 & 0,003312 & \multirow{2}{*}{0,000440} \\
\hline $\mathrm{JAGA}^{*}$ & 5 & 0,002872 & \\
\hline RIKKU & 2 & 0,001149 & \multirow{2}{*}{0,000203} \\
\hline $\mathrm{RIKKU}^{*}$ & 4 & 0,000946 & \\
\hline JOO & 12 & 0,006893 & \multirow{2}{*}{0,000032} \\
\hline $\mathrm{JOO}^{*}$ & 29 & 0,006861 & \\
\hline
\end{tabular}

Kõik objektifraasis samalaadselt kasutatud verbid on aspektverbid, v.a partitiivverb mängima. Nende verbide vormisagedus EVKK-s (tekstisagedus) ja FES-is (sõnastikusagedus) on küll erinev, kuid vahe verbitüvede osakaalu aritmeetiliste keskmiste vahel toob esile tänapäevases ja varasemas keelekasutuses samalaadselt kasutatud verbid, millele objektifraasi analüüsis saab tugineda. Võrdluseks: kuigi eesti kirjakeele sagedus- 
sõnastiku aluseks pole objektifraasid, vaid üldkogum, kuuluvad ka siin üheteistkümne sagedasema verbi hulka semantiliselt hajusad tuumverbid, sh saama, pidama, tegema, võtma ja andma. Võrdlus kinnitab veel kord teada-tuntud tõsiasja, et olenemata valimist, selle mahust ja sageduse esiletoomise metoodikast on semantiliselt markeerimata avaratähenduslikud tuumverbid keelekasutuses kõige sagedasemad (vrd ka Tragel 2003; Pajusalu jt 2004).

Edasine eesti õppijakeele objektifraasi analüüs on piiratud juhuvaliku põhjal nelja tuumverbiga: andma, tegema, võtma ja saama. Nende verbidega oli kokku 1098 vormikasutust, k.a kordused (tegema - 480, andma - 237, saama - 217 ja võtma - 164). Järjestades vormid korduvuse alusel, saame ülevaate erinevate verbivormide kasutusparadigmast (vt tabel 2). Kõige sagedamad verbivormid on _V_da (287 korda),_V_b (224 korda) ja _V_s (114 korda). Verbidega tegema, andma ja võtma kasutatakse sageli ka vorme_V_vad (70 korda),_V_sid (69 korda), _V _ ti (60 korda),_V_sin (46 korda),_V_ma (45 korda) ja _V_n (37 korda). Samas pole saama-verbiga eespool loetletud vorme (saavad, said, saadi, sain, saama, saan) üldse kasutatud. Vorm _V_o esineb vaid verbidega saama ja võtma (vastavalt 25 ja 6 korda) jne. Niisiis on õppijakeele valimi verbivormide kasutusparadigma asümmeetriline ja mittetäielik, see ei lange kokku eesti verbi morfoloogilise paradigmaga ega peagi kokku langema: vormide tekstisagedus ei sõltu keele süsteemist (produktiivsetest või mitteproduktiivsetest klassidest jm), vaid kommunikatiivsest vajadusest informeerida, fokuseerida, mõjutada, hinnanguid anda, teada saada jne.

Järgnevalt on tegema-, andma-, saama- ja võtma-verbide objektifraasid jagatud kahte rühma: leksikaalselt markeeritud objektifraasid, mis sisaldavad objekti ja tegevust määratlevaid markereid, ja objektifraasid, mis neid ei sisalda (vt tabel 3). 
TABEL 2. Eesti õppijakeele objektifraasi verbivormide tekstisagedus

\begin{tabular}{|l|c|c|c|c|c|}
\hline \multirow{2}{*}{ Vorm } & \multicolumn{5}{|c|}{ Verb } \\
\cline { 2 - 6 } & tegema & $\boldsymbol{a n d m a}$ & $\boldsymbol{s a a m a}$ & $\boldsymbol{v} \tilde{\boldsymbol{o} t \boldsymbol{m a}}$ & Kokku \\
\hline _V_da & 120 & 22 & 110 & 35 & 287 \\
\hline _V_b & 80 & 76 & 47 & 21 & 224 \\
\hline _V_s & 52 & 42 & 4 & 16 & 114 \\
\hline _V_vad & 39 & 21 & 0 & 10 & 70 \\
\hline _V_sid & 34 & 24 & 0 & 11 & 69 \\
\hline _V_ti & 28 & 10 & 0 & 22 & 60 \\
\hline _V_sin & 26 & 7 & 0 & 13 & 46 \\
\hline _V_ma & 23 & 19 & 0 & 3 & 45 \\
\hline _V_n & 26 & 6 & 0 & 5 & 37 \\
\hline _V_o & 0 & 0 & 25 & 6 & 31 \\
\hline _V_takse & 15 & 5 & 2 & 4 & 26 \\
\hline _V_sime & 21 & 1 & 0 & 2 & 24 \\
\hline _V_ks & 0 & 0 & 17 & 0 & 17 \\
\hline _V_me & 6 & 1 & 0 & 7 & 14 \\
\hline _V_ge & 2 & 0 & 0 & 6 & 8 \\
\hline _V_ksid & 2 & 0 & 4 & 0 & 6 \\
\hline _V_ksin & 1 & 0 & 4 & 0 & 5 \\
\hline _V_des & 3 & 0 & 0 & 0 & 3 \\
\hline _V_site & 1 & 0 & 0 & 2 & 3 \\
\hline _V_ksime & 0 & 0 & 3 & 0 & 3 \\
\hline _V_taks & 0 & 2 & 0 & 0 & 2 \\
\hline _V_neg o & 1 & 0 & 0 & 0 & 1 \\
\hline _V_ksid & 0 & 1 & 0 & 0 & 1 \\
\hline _V_ksite & 0 & 0 & 1 & 0 & 1 \\
\hline _V_d & 0 & 0 & 0 & 1 & 1 \\
\hline Kokku & 480 & 237 & 217 & 164 & 1098 \\
\hline
\end{tabular}


TABEL 3. Leksikaalsete markerite kasutamine objektifraasi sagedasemate verbidega eesti óppijakeeles

\begin{tabular}{|l|c|c|c|c|}
\hline Verbid & $\begin{array}{c}\text { Objektifraasi } \\
\text { verbivormid }\end{array}$ & $\begin{array}{c}\text { Objekti } \\
\text { markeerimine }\end{array}$ & $\begin{array}{c}\text { Tegevuse } \\
\text { markeerimine }\end{array}$ & $\begin{array}{c}\text { Markerita } \\
\text { objektifraasid }\end{array}$ \\
\hline tegema & 480 & 139 & 111 & 230 \\
\hline andma & 237 & 61 & 72 & 104 \\
\hline saama & 326 & 106 & 35 & 185 \\
\hline võtma & 164 & 56 & 26 & 82 \\
\hline Kokku & 1207 & 364 & 242 & 601 \\
\hline
\end{tabular}

Leksikaalseid markereid sisaldavaid ja mitte sisaldavaid objektifraase esines valimis peaaegu võrdselt, verbiga võtma täpselt samas mahus (vastavalt $56+26$ ja 82 juhtumit, vt tabel 3 ). Seega on objektifraase, milles objekti ja tegevust pole olnud vajadust määratleda, sama palju (kokku 601 juhtumit) kui markereid sisaldavaid kasutusi (kokku 606 juhtumit). Näiteks: tegema-verbi kasutati kokku 480 korda, millest 250 korral esines kas objekti või tegevust markeerivaid lekseeme ja 230 korral ei olnud nende kasutamist peetud vajalikuks; andma - vastavalt 133 ja 104 juhtumit, saama - 141 ja 85, võtma - 82 ja 82. Kuna markeeritud ja markeerimata objektifraaside sagedus õppijakeele valimis on sarnane, siis võrreldakse neid omavahel, tuues esile tendentsid objekti ja tegevuse keelendamisel.

\section{Millest räägib objekti ja tegevuse markeerimata jätmine}

Objekti ja tegevuse on eesti keele õppijad markeerimata jätnud sama sageli kui neid markeerinud (vt tabel 3). Järelikult pole markeerimine teatud tingimustel vajalik. Analüüsi tulemused näitavadki, et tegema-, andma-, saama- ja võtma-verbide objektifraasid on $\varnothing$-markeeritusega idiomaatilised terviküksused või nende mitteidiomaatilised struktuurianaloogid, milles verbivormide valik on rangelt piiratud. Tegu on verbi 
ja substantiivi püsiühenditega, mille seas on valdavalt esindatud tugiverbiühendid, "kus ühendi põhitähenduse annab noomen, verbi osaks on vaid verbile omaste grammatiliste tähenduste väljendamine" (vt Kaalep, Muischnek 2009: 160), nt nalja tegema, abi andma, algust saama, puhkust võtma. See on kooskõlas tuumverbide abstraktse semantikaga. Muud verbi ja substantiivi püsiühendid, mida eesti õppijakeeles on kasutatud $\varnothing$-markeeritusega objektifraasides, võiks jagada erinevate tunnuste alusel idiomaatilistest üksustest ja kollokatsioonidest (nt silmi tegema ja sõna saama) kuni vabade sõnaühenditeni, kuid keelekasutuse seisukohalt pole see obligatoorne. Oluline tunnusjoon, mis määrab nende keeleüksuste kasutuse, seisneb selles, et kõik $\emptyset$-markeeritusega objektifraasi verbi ja substantiivi ühendid on süntaktilise struktuuri poolest ühesugused, nende tekstikasutust iseloomustavad kindlad morfosüntaktilised piirangud, neid kasutatakse kui semantilisi ja morfosüntaktilisi terviküksuseid, mille alusel ja substantiive leksikaalselt varieerides on mugav moodustada uusi samalaadseid ühendeid. Seetõttu on siinses uurimuses kasutatud $\varnothing$-markeeritusega objektifraaside kirjeldamisel idiomaatilist laadi terviküksuse ja selle mitteidiomaatilise struktuurianaloogi mõisteid ning vaadeldud koos nende kasutusele omaseid morfosüntaktilisi piiranguid.

Näiteks tegema-verbi on kasutatud da-infinitiivi (teha) ja indikatiivi oleviku 3. pöörde vormis (teeb); järgnevad indikatiivi lihtmineviku 3. pööre (tegi), oleviku mitmuse 3. pööre (teevad), lihtmineviku ainsuse 1. pööre (tegin). Niisugune on selle verbi kasutusparadigma markeerimata objektifraasis, millest üle kolmandiku on eesti keelele omased kinnistunud struktuuriga (verb + objektikäändeline substantiiv) idiomaatilist laadi terviküksused ja peaaegu kaks kolmandikku sama malli järgi moodustatud mitteidiomaatilised struktuurianaloogid, mida kasutatakse eesti keeles suhteliselt sageli: tegema ettepanekut, järeldust ( järeldama), karjääri, koostööd, kaastööd, tööd ( töötama), otsust ( otsustama), raha, remonti ( remontima), revolutsiooni, sisseoste, uuringuid ( uurima), vahet, vigu, sporti ( sportima), lóket, heina, plaani ( plaanima), ringi, imet, silmi, tuju, lõket, harjutusi ( harjutama), nalja 
( naljatlema), ajalehte, filmi ( filmima), lõunauinakut, ettepanekut, tantsu ( tantsima), eksperimenti ( eksperimenteerima), pilte ( pildistama), avastust ( avastama), leiba, käskkirja, kodutööd jm. Idiomaatilistes üksustes on nii verbivormide ja kui ka objekti käändevormide varieerumine piiratud, oppijad omandavad need fraasid terviküksustena. Ilmselt seetõttu on ka kõrvalekaldeid keelenormist vähe. Vigu tuleb ette enamasti mitteidiomaatilistes morfosüntaktilistes üksustes, milles esineb sõnade tähenduserinevusest ja häälduslikust lähedusest tingitud paronüümiat, samuti eksimusi sõnade semantilise seose vastu, nt ${ }^{\star}$ teha vaheldusi <teha vahetusi $>$, ${ }^{\star}$ teeb kannatusi <tekitab kannatusi $>$, ${ }^{\star}$ teeb laulupidu <korraldab laulupeo/laulupidu $>$, ${ }^{\star}$ teen näide $<$ toon näite $>$ jne. Leidub ka näiteid nominatiivi ülekasutusest objekti käändevormi valikul (teeb ${ }^{\star}$ lugemine $<$ lugemise $>$, teeb ${ }^{*}$ esileht $<$ esilehe/esilehte $>$, teeb ${ }^{\star}$ remont $<$ remonti $>$ ) jm.

Ülejäänud kolme verbi kasutuspiirangud $\emptyset$-markeeritusega objektifraasis on samalaadsed, nt andma-verb esines peamiselt indikatiivi oleviku ainsuse 3. pöördes (annab) ja lihtmineviku ainsuse 3. pöördes (andis), vähem on näiteid da-infinitiiviga ( $a$ nda). Selle verbi kasutusparadigma on veelgi piiratum kui tegema-verbil, korduma kippuvaid idiomaatilist laadi üksusi on kasutatud sagedamini kui nende mitteidiomaatilisi struktuurianalooge: andma abi ( abistama), nõu ( nõustama), vastust ( vastutama), võimalust ( võimaldama), impulssi, leiba ( toitma), suunda ( suunama), valgust ( valgustama), haridust ( harima), arstiabi ( arstima), käsku ( käskima), lootust, tõuke $(\sim$ tõukama), avaldust ( avaldama), hoogu, infot ( informeerima), lisa ( lisama), rõõmu ( rõõmustama), preemiat ( premeerima), teadmisi, ülevaadet, voolu, elu, eratunde jne. Vormivead peaaegu puudusid, paaril korral oli eksitud sõnade semantilise seose vastu ( ${ }^{*}$ andis algust $<$ tegi algust, alustas $>$, ${ }^{\star}$ andis mõju <mõjutas $>$ ).

Veelgi suuremad piirangud markeerimata ehk $\varnothing$-markeeritusega objektifraasis on saama- ja võtma-verbidel: saama esineb enamasti indikatiivi lihtmineviku mitmuse 3. pöördes (said), võtma aga peamiselt $d a$-infinitiivis (võtta) ja indikatiivi lihtmineviku mitmuse 3. pöör- 
des (võttis). Mõlema verbiga oli kasutatud idiomaatilist laadi üksuseid ja nende mitteidiomaatilisi struktuurianalooge, nt saama asja, haridust, algust ( algama), palka, preemiat, rakendust, tunnustust, vabadust, võimalust, õigust, kogemust, tööd ja võtma osa ( osalema), sõna, võimu, kartuleid, ravimeid, puhkust, laenu, suunda ( suunduma) jne. Eksimusi semantilise seose vastu oli vaid võtma-verbi kasutamisel: ${ }^{\star}$ võtan infot $<$ saan infot $>,{ }^{\star}$ vôtta eksameid <sooritada eksameid $>$, ${ }^{\star}$ võttis aset $<$ leidis aset $>,{ }^{\star}$ vôttis harjutusi $<$ tegi harjutusi $>$.

Niisiis pole verbide tegema, andma, saama ja võtma objekti ega tegevust vajadust eraldi markeerida, kui objektifraasiks on rangelt piiratud vormikasutusega idiomaatilist laadi terviküksus või selle mitteidiomaatiline struktuurianaloog. Kuna pool eesti õppijakeele analüüsitud objektifraasidest on $\varnothing$-markeeritusega kinnistunud struktuuri ning piiratud vormikasutusega mitmesõnalised keeleomased üksused, mis on morfosüntaktiliselt suhteliselt lihtsad, siis on õppijad need ka kenasti omandanud. Suuremaid raskusi võivad tekitada objekti leksikaalse varieerimise semantilised piirangud ehk normipärane semantiline seos verbi ja substantiivi vahel (miski ei saa võtta aset, küll aga saab miski leida aset).

\section{Mida eesti õppijakeele objektifraasis markeeritakse}

Objektifraasis on leksikaalsete markeritega määratletud kas objekti või tegevust. Reeglina on markereid sisaldavad fraasid verbi ja substantiivi vabad sõnaühendid. Tavaliselt esineb neis päris palju objektikäände kasutuse ja täiendsõna põhisõnaga ühildumise vigu, samuti rektsioonimalli varieerumist, eksimusi sõnade semantilise seose piirangute vastu ning nominatiivi eelistamist teistele grammatilistele käänetele. 


\subsection{Objekt}

Objekti on tavapäraselt markeeritud kvalitatiivselt (tegema 108, saama 80, andma 48 ja võtma 24 korda): 1) viitavate-identifitseerivate pronoomenite (nt see, ise) ja possessiivpronoomenitega meie, minu, mu, sinu, oma (nt saada see eriala, teevad meie elu, võta ${ }^{\star}$ sinu $<$ minu > auto, andsid oma elu, teha oma valik) ning 2) adjektiividega (nt tegema sõjaväelise ettevalmistuseksami, anda täpset ${ }^{*}$ vastest, andis ${ }^{\star}$ häid nõu, saab ${ }^{\star}$ normaalne palk, saada ${ }^{\star}$ halvad emotsioonid jne) (vt tabel 4). Lastekeele uurijad on käsitlenud pronoomeneid koos substantiiviga kui referendi definiitsuse/ indefiniitsuse määratlejaid, mida kasutatakse referendi esmamainimisel, viidates uuele või tuntud referendile jm (vt Kirsipuu jt 2012: 100). Õppijakeele objektifraasi analüüs näitab, et nii pronoomeneid kui ka adjektiive on substantiivi laiendsõnana kasutatud kui objekti kvalitatiivselt konkretiseerivaid lekseeme.

Harvem esineb objekti kvantitatiivset konkretiseerimist ehk kvantifitseerimist (võtma 28, tegema 21, saama 14 ja andma 10 korda), mida pole kerge eristada tegevuse kvantifitseerimisest (vt allpool), nt võtab palju aega, teeb palju ${ }^{*}$ probleemi, andis palju piima, saab palju head heina. Kvantifitseerimise alla kuulub ka viitamine objekti ebamäärasusele (tegema-verbi objektiga 10, andma 2 ja saama 2 korda), nt tegime *igasugusi teste, tegime mitmesuguseid kokkuvõtteid, teha muud asjad, tegid mingit tööd, teha mõned kokkuvõtted jne (vt tabel 4). Niisiis on eesti õppijakeele objektifraasis kvantifitseeritud objekti hulka ja ebamäärasust.

TABEL 4. Objekti leksikaalne markeerimine eesti óppijakeeles

\begin{tabular}{|l|c|c|c|c|}
\hline Objekti markeerimine & tegema & andma & saama & võtma \\
\hline $\begin{array}{l}\text { 1. Objekti kvalitatiivne } \\
\text { konkretiseerimine }\end{array}$ & 108 & 48 & 80 & 24 \\
\hline $\begin{array}{l}\text { 2.1. Objekti hulga } \\
\text { markeerimine }\end{array}$ & 21 & 10 & 14 & 28 \\
\hline $\begin{array}{l}\text { 2.2. Objekti ebamäärasuse } \\
\text { markeerimine }\end{array}$ & 10 & 2 & 2 & 0 \\
\hline
\end{tabular}




\subsection{Tegevus}

Tegevust on leksikaalselt markeeritud peamiselt adressaadiga (andma 50, tegema 33, võtma 12, saama 11 korda). Seda mõistet käsitletakse siinses analüüsis katusmõistena, seega tunduvalt avaramalt traditsioonilisest: silmas pole peetud vaid isikut, kelle poole kõneleja pöördub oma pragmaatiliste eesmärkide täide viimiseks. Objektifraasi tegevust markeeriva adressaadi mõiste võib hõlmata patsienti, benefitsienti jt sündmuses osalejaid. Tavaliselt on adressaadi tähenduses kasutatud pronoomeneid, mis määratlevad semantiliselt tegevuse sihtpunkti: tegi temaga ${ }^{\star} k o o s t o ̈ o ̈$, tegi ${ }^{\star}$ Branderi jaoks ettepaneku, teevad meist laulurahva, teha ise ${ }^{*}$ indale tunniplaani, andis Eestile õiguse, saada endale ${ }^{*}$ kõrghariduse, võtta teiega ühendust jne.

Probleemne koht on tegevuse kvantifitseerimine (vt eespool) ning rõhutatud esiletoomine. Põhimõtteliselt võib objekti ja tegevuse kvantifitseerimist mitte eristada ja vaadelda neid koos, mis siinse uurimuse põhjal on õigustatud lähenemine. Samas võib ühte objektifraasi tajuda siiski mitmeti (kvantorsõna laiendab nii verbi kui ka objekti). Sel juhul on mõttekas vaadata pikemaid konkordantsiridu, ent mõnikord pole selleski tuge. Näiteks põhimõtteliselt võib kvantorit sisaldavat objektifraasi saada palju kogemusi interpreteerida mitmeti - kas midagi tahetakse palju saada või on võimalik saada palju kogemusi. Emakeelekõneleja jaoks on see mõnevõrra kohatu probleemiasetus, sest oma keelekompetentsile tuginedes peab ta kvantorsõna automaatselt substantiivi laiendiks, samas kui teise keele õppijas tekitab see küsimusi - ta vajab kasutusreegleid ja -malle. Semantilise seose tugevus kvantorsõna ja substantiivi vahel pole ühesugune, pigem on tegu skaalaga, mille ühes otsas on objektifraasid nagu võtab palju aega, tegime palju eksperimente, keskel saab hulga rohkem informatsiooni ning teises otsas teeb rohkem spontaanseid fotosid. Võrdle: 1) tegema-verb - tegema palju ${ }^{\star} k i$ irjalikuid <kirjalikke> töid, vigu, nii palju tööd; tegi palju proove, tööd; tegid palju laulupidusid, vigu; tegin palju harjutusi, pilte; teha palju (kodu)tööd; tehakse palju leiutisi; 2) andma-verb - anda palju raha; annab palju jõudu, armastust, *või- 
maluse, võimalusi; annavad palju kasumit; 3) saama-verb - saab palju informatsiooni, pappi, raha; saada palju informatsiooni, kogemusi, raha, teadmisi. Kvantorsõna palju on õppijakeeles kasutatud ka keskvõrdes: tegema rohkem ${ }^{\star}$ pidusi<d $>$, ${ }^{*}$ laulupidusi $<d>$ ja rahvatantsu, teha rohkem kahju; saada rohkem ${ }^{\star}$ rägimis oskust, võimalikult rohkem palka, saaksid rohkem ${ }^{*}$ avaliuku infot; andis rohkem liikumisvabadust, andma rohkem töökohti, annab rohkem võimalusi.

Võib-olla tooks siinkohal suuremat selgust tajutest, kuid käesoleva uurimuse raames pole seda tehtud. Paistab nii, et objektifraasi kvantitatiivne konkretiseerimine on õppija keelekasutusele omane, sest näiteid on üsna rohkesti. Lausestust ning sõnajärge muutes on võimalik objekti ja tegevuse kvantifitseerimist selgemalt eristada. Näiteks: Kogemusi tahaksin ma seal saada palju/palju saada ja Ma tahaksin seal palju kogemusi saada.

Ainult tegevust kvantifitseerivate markerite kasutusnäiteid on õppijakeeles vähe. Enamasti on need määrsõnalised verbilaiendid nagu teeb järjekordselt kannapöörde, teeb seda ${ }^{*}$ suure eduga <edukalt>; annab

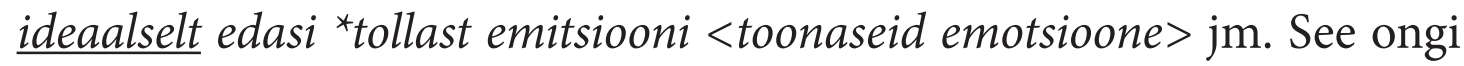
sisuliselt ainus tegevuse kvantifitseerimise võimalus.

Objektifraasi markeerimist rõhupartikliga esines vaid tegema- ja andma-verbiga. Sel eesmärgil on õppijakeeles kasutatud rõhupartiklit $k a$, nt teha ka vaheaeg, tehti $\underline{k a}$ vigu; andis ka välja mitmeid raamatuid, andma ka kórgharidust, andsid ka julguse, raha, *annab ka erinevat probleemid < toob ka esile erinevaid probleeme>, annab ka head nõu, ${ }^{*}$ annab ka võimalus. Kui vaadelda lähemalt, kas rõhupartikkel markeerib rohkem tegevust või objekti, siis on tegu sama asjaga, kui kvantorite kasutamisel. Seetõttu ei peatuta siinses artiklis pikemalt ka nendel rõhupartiklit sisaldavatel objektifraasidel. 


\section{Kuidas on markeeritud objekti ja tegevust}

\subsection{Objekt}

Objekti on kõige sagedamini markeeritud kvalitatiivselt (vt tabel 4). Sel eesmärgil on kasutatud viitavaid-identifitseerivaid pronoomeneid (nt see, ise) ja possessiivpronoomeneid meie, minu, mu, sinu, oma. Näiteks: teeb selle ajalehe, teeb ${ }^{*}$ seda muinasjutt <teeb selle muinasjutu>, ${ }^{*}$ tegi katki

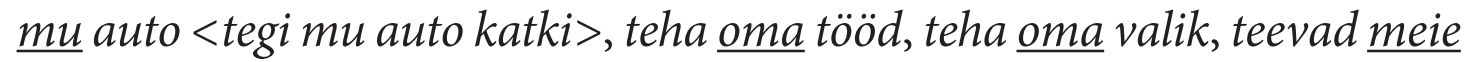
elu; saada see eriala; võta ${ }^{*}$ sinu $<$ minu> auto; andsid oma elu jne.

Sageli kasutatud adjektiivsete markerite valik on piiratud kahe-kolme lekseemiga: hea (eriti koos saama-verbi objektiga), uus (v.a võtma-verbi objekt), tegema-verbi objektiga ka suur. Harva on kasutatud adjektiive huvitav, normaalne ja eesti. Näiteks: teha häid otsuseid, andis ${ }^{*}$ häid nõu, andma hea kasumi, ${ }^{*}$ ootta head tulemused, saada ${ }^{\star}$ heat tööd, annab uusi muljeid, teha ${ }^{*}$ uut laule, saaks uusi teadmisi, ${ }^{*}$ võeti uut teadust, tegid suuri ettevalmistusi, andis ${ }^{*}$ suurt võimalust, saada suurt palka, ${ }^{*}$ vótavad suurt koormust jne. Ligi poole adjektiivsetest markeritest moodustavad aga ainukordsed ja mõned kaks korda esinenud lekseemid (nt teen $\underline{k o d u-}$ seid ${ }^{*}$ tööd, tegi raskemaid töid, tegid ${ }^{*}$ igapäevased tööd, teha ${ }^{\star} k$ keerulistest tööd, teha praktilist tööd, teha ${ }^{*}$ vajalikut tööd). Üldiselt on objekti kvalitatiivselt markeerivate adjektiivide hulk piiratud, eriti võtmaverbi objektifraasis. Võrreldes tegema- ja saama-verbidega, on võtmaning andma-verbide objekti kvalitatiivselt harva markeeritud. Näiteks: 1) tegema-verbi objekti puhul - kodune, korralik, tähtis, erinev, rumal, ilus, temaatiline, sõjaväeline, kohustuslik, paha, raske, igapäevane, suurepärane, kange, naljakas, väike, arukas, õige, igav, kahekeelne, keeruline, modernne, praktiline, spetsiaalne, vajalik, huvitav, valitud, mittetoimiv; 2) andma-verbiga - emakeelne, täpne, keerukas, kasulik, rakenduslik, sini-must-valge, täielik, õige, kvaliteetne, suurepärane, tõetruu, tõsine, tühi, keskne, tugev; 3) saama-verbiga - säärane, samasugune, fantastiline, paha, suuline, erinev, halb, vajalik, kõrgem, musikaalne, omakeelne, positiivne, sobiv, täidetud, viimane, vajalik; 4) võtma-verbiga - vaimulik, tühi, globaalne, soome. 
Objekti kvantitatiivse markeerimise juhtumid ei olnud eriti sagedased (vt tabel 4): võtma-verbi objektiga 11 korda, tegema - 7, andma - 4, saama - 1. Kõige levinum marker on kvantorsõna palju. Joonistub välja kvantifitseerimise hierarhia: väga palju - päris palju - palju - rohkem piisavalt - vähem - natukene. Näiteks: võtab palju aega, võtab päris palju raha, võtab väga palju ruumi, võtta piisavalt puid, võtab vähem aega, võtan ${ }^{\star}$ natukene lilled; teeb palju ${ }^{\star}$ probleemi, teeb palju tööd, teen palju vigu, tehakse väga palju vigu, ${ }^{\star}$ tehti väga palju leiutisi; andis palju piima, anti välja palju kalendreid; saab palju head heina.

Vähesel määral on objekti kvantorina kasutatud ka numeraali: võeti vastu ainult 10 inimest, võtsin neli ajalehte jne. Numeraal moodustab koos objektiga tervikmõiste ega võimalda mitmeti interpreteerimist nagu nt kvantor palju (vt eespool). Iseloomulik on see peamiselt võtmaverbi objekti markeerimisele (kokku 10 näidet).

Objekti kvantorina on kasutatud ka sõnu kõik ja kogu, millel keeleõppijad eriti vahet ei tee. Nendega on markeeritud peamiselt võtma- ja tegema-verbide objekti: võtame ${ }^{\star}$ kõik prügi, võtame ${ }^{\star}$ kõik oma raha, võta kogu minu aeg, võtsid ${ }^{\star}$ kogu külad, võtta vastu ${ }^{\star} k$ kõik informatsioon, võtta kõik jõud; teevad kogu töö, tegema kõik võimaliku, teha kõike võimalikku.

Objekti ebamäärasust on markeeritud harva: tegema-verbi objektiga 10 korda (nt tegid mingit tööd, tegime *igasugusi teste, tegime mitmesugu-

seid kokkuvõtteid, teha muud asjad, teha mõned kokkuvõtted), andma- ja saama-verbide objektiga vaid 2 korda (saaksin mingi teatri, saada ${ }^{*}$ mingeid uut teaduseid; andma mingit osa, andis välja mitmeid brožüüre), võtma-verbi objektiga üldse mitte. Markerina on kasutatud peamiselt lekseemi mingi (vt ka eespool).

\subsection{Tegevus}

Verbi tegevust on kõige sagedamini markeeritud adressaadiga (106 korda), järgnevad mõned selged kvantifitseerimise juhtumid. Rektsioonimalli alusel peaks tegema- ja andma-verbi adressaat olema tavaliselt allatiivne (kes teeb, annab kellele (millele) (keda) mida) ning saama- ja 
võtma-verbil ablatiivne (kes saab kellelt (kelle käest) mida ja kes võtab kellelt (kelle käest) - millelt mida). Rektsioonimalli kohaselt on õppijakeele objektifraasis kasutatud vaid verbi andma, selle verbi tegevust on adressaadiga markeeritud teistest verbidest märgatavalt sagedamini. Markeriks on peaaegu eranditult allatiivsed personaalpronoomenid, v.a ainsuse 3. isik (vt tabel 5). Adressaadina on eesti oppijakeele objektifraasis vastandatud nemad ja meie ning sina ja mina.

TABEL 5. Andma-verbi tegevuse markeerimine adressaadiga

\begin{tabular}{|l|l|c|l|c|}
\hline Isik & \multicolumn{1}{|c|}{ Ainsus } & Sagedus & \multicolumn{1}{c|}{ Mitmus } & Sagedus \\
\hline 1. isik & minule, mulle & 2 & meile & 14 \\
\hline 2. isik & sulle & 9 & teile & 1 \\
\hline 3. isik & temale, talle- & 0 & nendele, neile & 14 \\
\hline
\end{tabular}

Näiteks:

ainsuse 1 . isik - anda minule ${ }^{\star} \ddot{u ̈ l e n d a v a t ~ t u n n e t, ~}{ }^{\star}$ annab $\underline{\text { mule }}<$ mulle $>$ vaimustust;

ainsuse 2. isik - annab sulle vabaduse, vabanduse, vajaduse, energiat; annavad sulle *hea haridus, hea tuju, ettekujutuse;

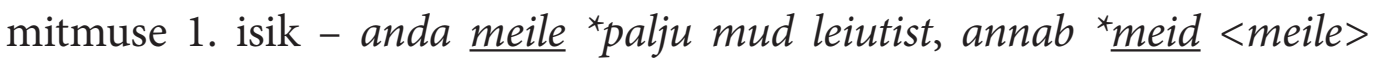
võimalust, annab meile elektri, ettekujutuse, ${ }^{*}$ informatsioone, palju võimalusi, teadmisi, ${ }^{*}$ teemat, toidu, tõenäolisi võimalusi, ${ }^{*}$ õimalus, võimalusi, ${ }^{*}$ normaalne elu, ôigust;

mitmuse 2. isik - anda ${ }^{\star}$ teie $<$ teile $>$ võimalus;

mitmuse 3. isik - anda nendele ainult õigus, haridus, ${ }^{*}$ maitsvat puuvilju, andsid nendele jõudu ja tähtejõudu, õigust, annavad nendele raha ja anda neile julgust, piima, usku, ${ }^{*}$ võimalust, andsid neile ${ }^{*}$ usk, annab neile rohkem võimalusi, vaimse naudingu, anti neile mõned esemed.

Toodud näidetes hakkab silma mitmuse 3. isiku peaaegu võrdne kasutamine nii pika kui ka lühivormiga. Ilmselt poleks pikka vormi iga kord vaja olnud, nt anda nendele ainult õigus, haridus, ${ }^{*}$ maitsvat puuvilju jne. Personaalpronoomeni pika ja lühivormi valik tuleneb eesti keeles kõneakti pragmaatikast, kuid mitmetel põhjustel ei tunneta keeleõppijad 
neid erinevusi. Samas ei tea me päris täpselt, mis tingimustel emakeelekõneleja ikkagi lühivormi eelistab ja kas pika vormi kasutamine on alati tingitud vajadusest adressaati rõhutada, esile tuua, fookusesse tõsta. Vrd: mis neil/nendel tehagi; .. nagu poleks neil/nendel muud paremat anda jne.

Üksikjuhtumitel on andma-verbi tegevust markeeritud substantiivse adressaadi või isiku- ja kohanimedega: anda ${ }^{\star}$ nortele huvi, annab jõudu inimestele, oma ${ }^{*}$ studentidele palju erinevaid võimalusi, andis Branderile plaani, Eestile ${ }^{*}$ voimalust, õiguse, andma kõigile head tingimused, annab ühele *head võimalusi.

Sageduselt järgmine verb, mille tegevust adressaadiga markeeritakse, on tegema. Rektsioonimallile vastavalt peaks ka tegema-verbil olema allatiivne adressaat, kuid õppijakeeles on kasutatud muid käändeid, kõige sagedamini elatiivi, nt teevad ${ }^{\star} \underline{\text { temast }}$ koori, teevad neist laulurahva, teevad ${ }^{*}$ minust laulurahva, teeb ${ }^{*}$ ennast $<$ endast $>$ laulurahva, teeb ${ }^{*}$ eestirahvast laulurahva, teeb eesti rahvast laulurahva, teeb

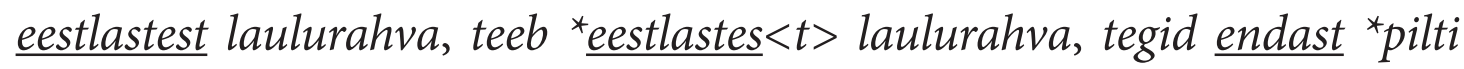
$<$ pildi $>$. Allatiivset adressaati esines veidi vähem, nt tegi Punamütsikesele punase mütsi, teha endale ${ }^{*}$ kunstrüpsmed ja kunstjuuksed, teha ise ${ }^{*}$ indale $<$ endale > tunniplaani, teha iseendale .., teevad teine-teisele ${ }^{*}$ kingitusele, teevad ${ }^{\star}$ omale $<$ endale $>$ söögi. Järgnesid juhtumid, kus adressaati märgitakse kaassõnafraasiga: tegi Brander jaoks ${ }^{*}$ ettepanek $<u>$, tegi Branderi jaoks fotokava, tegi Branderi jaoks planeeringu. Kaassõnafraasi on võimalik asendada allatiiviga (tegi Branderile ettepaneku), kuid õppijakeeles pole seda kasutatud. Üksikjuhtumitel esines komitatiivset adressaati (tegi temaga ${ }^{*}$ koostöö $<d>$, teha seda inimestega).

Niisiis on tegema-verbi puhul adressaati keelendatud erinevate sõnaliikide (pronoomenid, substantiivid, sh isikunimed) ja käändevormidega, osaliselt ka normivastaselt. Kuigi tegema-verbi adressaati on sagedamini markeeritud pronoomenitega (sh personaalpronoomenid), puudub selles andma-verbi kasutusele omane regulaarsus. Mitteallatiivse adressaadi kasutamine õppijakeeles paistab olevat üldse õppija emakeele mõjuline: elatiivi võib seostada vene keele tegema-verbi rektsioonimalliga (tegema kellestki-millestki kedagi-midagi), sama võib 
oletada ka seoses kaassõnafraasi eelistamisega allatiivsele adressaadile (vn k tegema midagi kellegi-millegi jaoks). Ilmselt johtub ühe ja sama verbi ühe rektsioonimalli asendamine teise rektsioonimalliga raskustest sõna sekundaarsete tähenduste tajumisel ja eristamisel, millega kaasneb rekstsioonistruktuuride varieerumine.

Võtma- ja saama-verbide objektifraasis on tegevust adressaadiga markeeritud tunduvalt harvem (vastavalt 12 ja 11 korda) kui eespool kirjeldatud juhtumitel. Rektsioonimalli kohaselt peaks võtma- ja saamaverbi adressaat olema ablatiivis (kes võtab kellelt-millelt mida või kelle käest kelle-mille ja kes saab kellelt mida või kelle käest mida). Analüüs näitas, et ka siin on adressaadiks põhiliselt pronoomenid, neid kasutatakse erinevates käänetes, kuid selles puudub regulaarsus. Näiteks: 1) võtmaverbi tegevust on markeeritud komitatiivse (võtta teiega, temaga ühendust), allatiivse ( ${ }^{*}$ võtab endale presidendi, võtavad endale ${ }^{*} u u s$ töö <uue töö>) ja ablatiivse adressaadiga (võtsid oma lastelt kõik ära), samuti kaassõnafraasiga (võttis tööle Branderi asemel uue fotograafi); 2) saama-verbi tegevust on markeeritud allatiivse (saada ${ }^{*}$ enda $<l e>$ uusi tuttavaid, endale ${ }^{\star} k i n d l a ~ t u l e v i k u,{ }^{\star} k \tilde{r}$ rghariduse, saaks $\underline{\text { endale }}{ }^{\star}$ oma koolitunnistus $<e>$, saaksite ${ }^{\star} \underline{\text { meile }}<$ meid $>$ aidata) ja elatiivse adressaadiga (<ei $>$ saa midagi ${ }^{\star}$ óppekavas $<t>$, saab sellest ${ }^{*}$ rahuldus $<e>$, saaksid sellest kasu), samuti kaassõnafraasiga (saaks ${ }^{\star} \underline{\text { Teil }}<$ teie juures $>$ töökohta). Ablatiivita vormistatud adressaadi kasutamist õppijakeeles võib emakeelekõneleja tajuda kas eksimusena sõnade semantilise seose (nt presidenti ei võeta, vaid valitakse ja uus töö leitakse, mitte ei võeta) või rektsioonistruktuuri vastu (nt saaksite ${ }^{*}$ meile < meid>aidata - õppija emakeelse rektsioonimalli mõjul on eesti keeles objektina kasutatavast personaalpronoomenist saanud adressaat).

Niisiis on eesti õppijakeeles tegevust markeeritud peamiselt adressaadiga. Sel eesmärgil on tavaliselt kasutatud pronoomeneid, andmaverbi objektifraasis regulaarselt allatiivseid personaalpronoomeneid (v.a ainsuse 3. isik). 


\section{Kokkuvõte}

Eesti õppijakeele objektifraasi analüüs näitas, et võrdse sagedusega kasutatakse kahte tüüpi kontekste: 1) objekti ja tegevust markeerimata ehk $\varnothing$-markeeritusega ja 2) leksikaalselt markeeritud fraase.

Markeerimata objektifraasi iseloomulikud tunnused on idiomaatilisus, terviklikkus, kinnistunud struktuur, morfosüntaktiline lihtsus ja verbi vormivaliku range piiritletus. Ka mitteidiomaatilisi $\emptyset$-markeeritusega objektifraase kasutatakse sama struktuurimalli alusel, mistõttu saab neid pidada idiomaatilise objektifraasi struktuurianaloogiks (vrd silmi tegema > tööd tegema > lóket tegema; nõu andma > võimalust andma > avaldust andma; asja saama > haridust saama jms). Vastavalt idiomaatilisuse-mitteidiomaatilisuse astmele joonistub välja $\varnothing$-markeeritusega objektifraaside idiomatiseerituse hierarhia. $\varnothing$-markeeritusega objektifraasis sagedamini kasutatud verbivormid on indikatiivi mitmuse 1 . ja 3. pööre, harvem da-infinitiiv. Kas õppijakeele markeerimata objektifraasi piiritlevad tunnusjooned on iseloomulikud ka standardkeelele, seda peaks näitama võrdleva analüüsi tulemused. Ilmselt selgub siis samuti, kuivõrd efektiivne võib olla morfosüntaktilise struktuuri kompaktsus, lihtsus ja kõrge kasutussagedus idiomaatilist laadi üksuste omandamisel ning produtseerimisel.

Paralleelselt analüütiliste üksustega kasutatakse eesti keeles ka samatähenduslikke sünteetilisi, nt järeldust tegema järeldama, suunda andma $\sim$ suunama, algust saama algama, osa võtma osalema. Toodud näidetes moodustavad analüütilised ning sünteetilised üksused vastanduse, mille markeerimata liige on hajusama tähenduse ja lihtsama struktuuriga sünteetiline üksus. Samas pole sugugi kindel, kas emakeelekõneleja kasutab sünteetilist üksust markeerimatuse ja struktuuri lihtsuse tõttu sagedamini ja peab seda loomulikumaks kui samatähenduslikku analüütilist üksust. Ilmne on vaid see, et vene emakeelega õppija lähtekeeles on olemas samalaadne analüütilise ja sünteetilise verbi(konstruktsiooni) kontekstuaalne aspektuaalne vastandus, kus markeerimata liige on semantiliselt hajusam ja struktuurilt lihtsam sünteetiline verb, nt osa 
võtma $\sim$ osalema $=$ принимать (imperfektiivne aspekt) $/$ принять ${ }^{*}$ (perfektiivne aspekt) участие участвовать (imperfectiva tantum). Selles mõttes on tegu lähte- ja sihtkeele vahelise sümmeetriaseosega, mille tajumine peaks sihtkeele omandamist toetama. Pealegi on sihtkeele nähtusi, mis pole lähtekeelest markeeritumad, suhteliselt kerge omandada. Samas on eesti keele õppija semantiliselt hägusatele ja morfosüntaktiliselt varieeruvatele sünteetilistele verbidele (väljendverbid) ja verbikonstruktsioonidele eelistanud kinnistunud struktuuriga sageli kasutatavaid idiomaatilist laadi terviküksusi, mille alusel ja analoogiat rakendades saab produtseerida uusi. Seega on kinnistunud struktuuri ning vormikasutusega sageli esinevaid idiomaatilist laadi terviküksuseid kergem omandada kui leksikaalgrammatiliselt varieeruvaid sünteetilise verbi konstruktsioone. Raskendav asjaolu on piirangud sõnade semantilises seoses, kus kõrvuti analoogia ja sümmeetriaseostega ilmneb keeltevahelist asümmeetriat ( $\mathrm{nt}^{*}$ andis algust <tegi algust, alustas $>,{ }^{*}$ vottis aset $<$ leidis aset $>$ ).

Markeeritud objektifraasi üldised tunnused on leksikaalgrammatiline varieeruvus ja mitteidiomaatilisus. Markeeritud objektifraasid jagunevad kaheks olenevalt sellest, kas määratletud on objekti või tegevust. Vahepealse juhtumi moodustavad objekti ja tegevuse kvantitatiivne markeerimine ning rõhutatud esiletoomine, kui kvantor ning rõhupartikkel markeerivad samaaegselt nii objekti kui ka tegevust (v.a numeraaliga markeerimine). Nimetatud protsess näib kaasnevat sõnajärje varieerumisega ning kulgeb selle taustal. Kas ka standardkeelega seoses võiks rääkida samast nähtusest, sellele peaksid vastuse andma eesti õppijakeele ja standardkeele võrdleva analüüsi tulemused. Igal juhul viitab õppija keelekasutus nähtuse olemasolule piisavalt selgesti.

Järgmine objekti ja tegevuse markeerimise eripära on seotud semantiliste tunnustega, mille alusel objekti ja tegevust referentsiaalselt identifitseeritakse. Nii on objekti markeerimisel olulised kaks tunnust: objekti kvaliteet ja kvantiteet, kolmas tunnus - objekti ebamäärane hulk - on fakultatiivne. Kvaliteet ja kvantiteet moodustavad dialektilise loogika seaduste järgi opositsiooni, mille markeerimata liige on kvaliteet (sisal- 
dab oma vastasliiget ja on seetõttu semantiliselt avaram mõiste). Järelikult on loomulik, et objekti on kõige sagedamini markeeritud just selle tunnusega - tegu on objekti markeerimise dominandiga. Oluline on, missugust kooki või missugust koogitükki keegi tahab võtta ja seejärel kui palju kooki või koogitükke tahetakse, kuid mitte see, kas objekt on määratud või määramata, konkreetne või abstraktne, tervik või osa jm. Küsimusele, kas tegu võiks olla vaid õppijakeelele omase nähtusega, saab täpsemalt vastata võrdluse põhjal standardkeelega. Esialgu paistab nii, et objekti ja selle käändekasutust uurides-õpetades hoitakse kiivalt kinni grammatikatraditsioonist, samal ajal kui keeleõppija tugineb semantilistele seostele ja valib keelekasutusele omase lihtsama ning loomulikuma tee.

Markeeritud objektifraasi tegevust on määratletud enamasti adressaadiga, mis on ka loomulik. Tegevust identifitseerides ei mõtle keelekasutaja aspektilisusele või näiteks ajalisele piiritletusele, teelisusele või ateelisusele - need tunnused iseloomustavad verbi lingvistilist kirjeldust. Ka siin on näha vastuolu selle vahel, mida keelt kasutades markeeritakse ning missugustele tunnustele tugineb grammatikakirjeldus. Keelekasutuse loogika ning grammatikareeglid on erinevad.

Nagu Ø-markeeritusega objektifraasis, nii on ka markeeritud objektifraasi keelendamisel kindlad piirangud, mida iseloomustab keeleline variatiivsus, mitteidiomaatilisus ja täiuslike paradigmade puudumine (vt eespool).

Nii on objekti kvalitatiivne ja kvantitatiivne markeerimine piiratud sõnaliigiliselt ja esinemissageduse poolest. Objekti kvalitatiivsel keelendamisel on regulaarselt kasutatud viitavaid-identifitseerivaid (nt see, ise) ja possessiivpronoomeneid (meie, minu, mu, sinu, oma) ning kolme adjektiivi (hea, uus ja suur). Üle poole kõikidest adjektiividest on ainukordsed, nende hulk on üsna piiratud. Objekti kvantitatiivse markeerimise levinum vahend on kvantorsõna palju, numeraali on harva kasutatud. Esile tuleb kvantifitseerimise semantilise hierarhia: väga palju - päris palju - palju - rohkem - piisavalt - vähem - natukene. Niisiis on objekti markeerimisel kindlad semantilised, leksikaalsed ja 
leksikaalgrammatilised piirid. Sageli kasutatud keelevahendid esinevad regulaarselt, kuid nende valik on piiratud (pronoomenid, adjektiivid hea, uus ja suur, kvantor palju).

Tegevuse markeerimisel on olulised morfosüntaktilised ja esinemissagedusega seotud piirangud. Sageli tuleb ette emakeelekõneleja seisukohalt ebaloomulikku keelekasutust, v.a andma-verb, mida on regulaarselt kasutatud eesti keele rektsioonimallile vastavalt ja adressaati regulaarselt allatiivsete personaalpronoomenitega keelendades (valdavalt mitmuse 1. ja 3. isik). Vähem näiteid oli ainsuse 2. isikuga, peaaegu või üldse mitte ainsuse 1. ja 3. isiku ning mitmuse 2. isikuga. Kasutussageduse põhjal tulevad esile isikuvastandused nemad - meie ja sina mina ning arvuvastandus mitmus/ainsus.

Ülejäänud verbide (tegema, võtma ja saama) tegevuse markeerimisel adressaadiga pole mitmuse 1. ja 3. isikut regulaarselt kasutatud, kõrvuti pronoomenitega esinevad ka substantiivid. Näiteks tegema-verbi objektifraasis on allatiivsele adressaadile eelistatud elatiivset, võtma- ja saama-verbi puhul komitatiivset ja allatiivset. Mitteloomulikku käändekasutust võivad põhjustada raskused, mis on õppijal verbi sekundaarsete tähenduste tajumisel ja sellest tulenevate rektsioonimuutuste eristamisel. Oma osa on siin ka tegema-, võtma- ja saama-verbi rektsioonimallide asümmeetrial õppija lähte- ja sihtkeele vahel. Selle tulemusena on loomulik rektsioonistruktuuride varieerumine kohati asendunud ebaloomuliku varieerumisega (hälve). Analüüs näitas, et adressaadi leksikaalgrammatilise varieeruvuse ning tegevusverbi tähenduskomponentide ja rektsioonimalli vahel on keerulised morfosüntaktilised seosed, mis idiomaatilist laadi terviküksuste omandamisega võrreldes tekitavad tunduvalt suuremaid raskusi.

Lõpetuseks saadud tulemuste usaldusväärsusest, milles on oluline osa analüüsi aluseks oleval objektifraaside valimil. Käesolevas uurimuses on selleks eesti keele erinevatele kasutusvariantidele iseloomulik ühisosa, mis saadud erinevatest korpusvalimitest objektifraaside tuumaks oleva verbitüve sageduse ja osakaalu võrdlemisel. Objektifraasi tekstija sõnastikusageduse põhjal esile toodud verbitüvede osakaalu võrdlus 
erinevates valimites näitas nii sagedaste tuumverbide kui ka harva esinevate täistähenduslike verbide samalaadset esindumust. Käesolevas uurimuses analüüsitud objektifraaside tuumaks on neli semantiliselt markeerimata tuumverbi, mida objektifraasis on kasutatud transitiivsete aspektverbidena (tegema, andma, saama, võtma). Järgnenud kvalitatiivne analüüs ja tulemuste interpreteerimine ei olnud üles ehitatud grammatikale, vaid markeerituse metamõistele: $\varnothing$-markeeritusega ja markeeritud objektifraas on üksteisele vastandatud, markeeritud fraasid on liigendatud nende semantiliste tunnuste alusel, mille abil õppija on objekti ja tegevust referentsiaalselt määratlenud.

\section{Tänusõnad}

Artikli valmimisel on olnud toeks riikliku programmi "Eesti keel ja kultuurimälu (2009-2013)" projekt "REKKi käsikirjaliste materjalide digiteerimine, Eesti vahekeele korpuse alamkorpuste loomine ja korpuse kasutusvõimaluste populariseerimine (2009-2013)", Eesti Teadusfondi grant 8222 "Ülekantud tähenduses fraasid eesti keele korpustes" ja Eesti Teadusfondi grant 8240 "Lähtekeele mõju ja teise keele omandamine: korpuspõhine uurimus".

\section{Kirjandus}

Aalberse, Suzanne, Jan Don 2011. Person and number synchronisms in Dutch. Morphology 21 (2), 327-350. http://dx.doi.org/10.1007/s11525-0109164-3

Battistella, Edwin L. 1990. Markedness: The Evaluative Superstructure of Language. Albany: State University of New York Press.

Бондарко, Александр 1971. Вид и время русского глагола. Значение и употребление. Москва: Просвещение.

Croft, William 1988. Agreement vs. case marking and direct object. - Michael Barlow, Charles Ferguson (Eds.). Agreement in Natural Language: Approaches, Theories, Descriptions. Stanford, CA: CSLI, 159-180.

Croft, William 2003. Typology and Universals. Second edition. Cambridge: Cambridge University Press. 
Eckman, Fred R. et al. (Eds.) 1986. Markedness. New York: Plenum Press.

Eckman, Fred R. 1977. Markedness and the Contrastive Analysis Hypothesis. - Language Learning 27 (2), 315-330. http://dx.doi.org/10.1111 /j.1467-1770.1977.tb00124.x

Eslon, Pille 2011. Millest räägivad eesti õppijakeele käändeasendused? - Lähivõrdlusi. Lähivertailuja 21, 45-64. http://dx.doi.org/10.5128/LV21.02

Эслон, Пилле, Антс Пихлак 1993. Вид и время. Таллинн: ТПедИ.

Eslon, Pille, Katre Õim 2010. Objektikäänete kasutamisest sageduse ja markeerituse seisukohalt. - ESUKA - JEFUL 1 (2), 69-89.

Greenberg, Joseph 1990. The relation of frequency to semantic feature in a case language (Russian). - Keith Denning, Suzanne Kemmer (Eds.). On Language. Selected Writings of Joseph H. Greenberg. Stanford, CA: Stanford University Press, 207-226.

Grünthal, Riho 2010. Sijasynkretismi morfologian koetinkivenä. - ESUKA JEFUL 1 (2), 91-113.

Harbour, Daniel 2011. Descriptive and explanatory markedness. - Morphology 21 (2), 223-245. http://dx.doi.org/10.1007/s11525-010-9167-0

Haspelmath, Martin 2006. Against markedness (and what to replace it with). Journal of Linguistics 42 (1), 25-70. http://email.eva.mpg.de/ haspelmt/ Againstmarkedness.pdf (13.03.2012).

Haspelmath, Martin 2008a. A frequentist explanation of some universals of reflexive marking. - Linguistic Discovery 6 (1), 40-63.

Haspelmath, Martin 2008b. Frequency vs. iconicity explaining grammatical asymmetries. - Cognitive Linguistics 19 (1), 1-33. http://email.eva.mpg. de/ haspelmt/Iconicity.pdf (18.03.2012).

Jin, Lingxia 2008. Markedness and second language aquisition of word order in Mandarin Chinese. - Marjorie K. M. Chan, Hana Kang (Eds.). Proceedings of the 20th North American Conference on Chinese Linguistics (NACCL20), Vol. 1. Columbus, Ohio: The Ohio State University, 297-308.

Kaalep, Heiki-Jaan, Kadri Muischnek 2009. Eesti keele püsiühendid arvutilingvitikas: miks ja kuidas. - Eesti Rakenduslingvistika Ühingu aastaraamat 5, 157-172. http://dx.doi.org/10.5128/ERYa5.10

Kirsipuu, Helen, Piret Soodla, Renate Pajusalu 2012. Referentsiaalsed noomenifraasid laste narratiivides. - Rakenduslingvistika Ühingu aastaraamat 8, 91-107. http://dx.doi.org/10.5128/ERYa8.06

Lahiri, Aditi (Ed.) 2000. Analogy, Leveling, Markedness: Principles of Change in Phonology and Morphology. Berlin: Mouton de Gruyter. 
LaPolla, Randy J. 1995. On the utility of the concepts of markedness and prototypes in understanding the development of morphological systems. - The Bulletin of the Institute of History and Philology 66 (4), 1149-1185.

Lee, Hanjung 2001. Optimization in argument expression and interpretation: A unified approach. PhD dissertation. Stanford University. http://www.blutner.de/Optimal/dat/HJ\%20Lee diss.pdf (20.03.2012).

Moravcsik, Edith A., Jessica R. Wirth 1986. Markedness - an overview. - Fred R. Eckman et al. (Eds.). Markedness. New York: Plenum Press, 1-11.

Pajusalu, Renate, Ilona Tragel, Ann Veismann, Maigi Vija 2004. Tuumsõnade semantikat ja pragmaatikat. Tartu: Tartu Ülikooli Kirjastus.

Pustet, Regina 2009. On the correlation between discourse frequency and structural complexity in markedness theory. - Discours 5, 1-22.

Remes, Hannu 2009. Muotot kontrastissa. Suomen ja viron vertailevaa taivutusmorfologiaa. Acta Universitatis Ouluensis B 90. Oulu: Oulun yliopisto.

Schaden, Gerhard 2008. Say hello to markedness. - Hans Broekhuis, Ralf Vogel (Eds.). Optimality Theory and Minimalism: Interface Theories. Linguistics in Potsdam 28, 73-97.

Tragel, Ilona 2003. Eesti keele tuumverbid. Dissertationes linguisticae Universtitatis Tartuensis 3. Tartu: Tartu Ülikooli Kirjastus.

Шелякин, Михаил 1983. Категория вида и способы действия русского глагола (Теоретическе основы). Таллин: Валгус.

Yamaguchi, Naomi 2008. Markedness, frequency: Can we predict the order of acquisition of consonants? - Proceedings of LingO 2007, Faculty of Linguistics, Philology, and Phonetics. University of Oxford, 236-243.

\section{Pille Eslon}

Tallinna Ülikooli eesti keele ja kultuuri instituut

Narva mnt 29

10120 Tallinn, Estonia

peslon@tlu.ee 


\title{
The lexical markedness of object and action in Estonian learner language
}

\author{
PILLE ESLON \\ Tallinn University
}

The study is part of a more extensive project in which Estonian learner language is compared against Estonian phraseological material and the standard Estonian. This article discusses marked object phrases, or those containing markers identifying object and action, and unmarked, or $\emptyset$-marked object phrases, describes their usage and semantic, lexicogrammatical, morphosyntactic and structural constraints. Object phrases have been extracted from a range of variants of language use according to their lexical and dictionary frequency. The comparison involves the percentage distribution of verb stems which form the head of the object phrase in selected subject groups, indicating the homogeneity of frequently occurring core verbs and rarely occurring content verbs.

This study is based on the selection of object phrases of four Estonian root verbs (andma 'to give', tegema 'to do', 'to make', võtma 'to take' and saama 'to get', 'to obtain'). The subsequent qualitative analysis and intepretation of results is based on the metaconcept of markedness and the law of dialectical logic rather than the grammatical system: the opposition of $\varnothing$-marked and marked object phrases, whereas the latter are described according to the semantic features used by an Estonian language learner to referentially interpret object (quality vs. quantity) and action (target, quantity, emphasis).

Keywords: Estonian learner language; lexical markedness; object phrases 